\title{
Polymer Additive Assisted Fabrication of Compact and Ultra-Smooth Perovskite Thin Films with Fast Lamp Annealing
}

\author{
Shoieb Shaik ${ }^{\dagger}$, Ziyou Zhou ${ }^{\dagger}$, Zhongliang Ouyang ${ }^{\dagger}$, Rebecca Han and Dawen Li ${ }^{*}$ \\ Department of Electrical and Computer Engineering, The University of Alabama, Tuscaloosa, AL 35487, USA; \\ sshoieb@crimson.ua.edu (S.S.); zhouziyou@gmail.com (Z.Z.); zouyang@crimson.ua.edu (Z.O.); \\ rihan@princeton.edu (R.H.) \\ * Correspondence: dawenl@eng.ua.edu \\ + S.S., Z.Z. and Z.O. contributed to this work equally.
}

check for updates

Citation: Shaik, S.; Zhou, Z.;

Ouyang, Z.; Han, R.; Li, D. Polymer Additive Assisted Fabrication of Compact and Ultra-Smooth Perovskite Thin Films with Fast Lamp Annealing. Energies 2021, 14, 2656. https://doi.org/10.3390/en14092656

Academic Editor: Emmanuel Kymakis

Received: 2 March 2021

Accepted: 26 April 2021

Published: 6 May 2021

Publisher's Note: MDPI stays neutral with regard to jurisdictional claims in published maps and institutional affiliations.

Copyright: (c) 2021 by the authors. Licensee MDPI, Basel, Switzerland. This article is an open access article distributed under the terms and conditions of the Creative Commons Attribution (CC BY) license (https:// creativecommons.org/licenses/by/ $4.0 /)$.

\begin{abstract}
Perovskite solar cells (PVSC) have drawn increasing attention due to their high photovoltaic performance and low-cost fabrication with solution processability. A variety of methods have been developed to make uniform and dense perovskite thin films, which play a critical role on device performance. Herein, we demonstrate a polymer additive assisted approach with Polyamidoamine (PAMAM) dendrimers to facilitate the growth of uniform, dense, and ultra-smooth perovskite thin films. Furthermore, a lamp annealing approach has been developed to rapidly anneal perovskite films using an incandescent lamp, resulting in comparable or even better device performance compared to the control hotplate annealing. The facile polymer additive assisted method and the rapid lamp annealing technique offer a clue for the large-scale fabrication of efficient PVSCs.
\end{abstract}

Keywords: perovskite solar cells; addition of polymer; rapid lamp annealing

\section{Introduction}

Hybrid perovskite emerges as a promising material in photovoltaics because of their high absorption coefficient, long carrier life time, and micrometer diffusion length [1-3]. There are mainly two kinds of well documented device architectures: mesoporous and planar heterojunctions [4-7]. In the mesoporous architecture, high temperature annealing is usually necessary to produce a $\mathrm{TiO}_{2}$ layer with good crystallinity, whereas planar heterojunction-based devices can be fabricated at low temperature. Unlike devices with mesoporous structure, in which the perovskite material can readily infiltrate into the porous matrix, planar perovskite solar cell devices usually suffer from pinhole and nonuniform coverage of perovskite thin films on the top of hole-transport layers [7]. The pinhole and non-uniformity are the major issues that are responsible for the poor device performance [8] Controlling the nucleation and formation of perovskite thin film in planar architecture is thus a main challenge for developing high-performance perovskite solar cells (PVSC) [9-13].

Considerable efforts have been dedicated to control the morphology and crystallinity of perovskite thin films [14-16]. The choice of solvent, [17-19] annealing temperature, [20-22] moisture, [23-26] and composition [27-30] have been proven as effective measures to tune the nucleation and growth of perovskite thin film. Additionally, incorporation of additives in the perovskite solution process has been demonstrated as a feasible way to improve the thin film coverage and crystallinity [31]. Different types of additives, including solvents, [32,33] inorganic acids, [34,35] metal halide salts, [36,37] organic halide salts, [38,39] have been implemented to perovskite thin films, which showed enhancement in device performance. In comparison, polymer additives have multiple potential advantages, such as improving the coverage of perovskite films, stabilizing the frame structure of perovskite and providing better resistance to humidity [31,40,41]. In 2015, Chang et al. reported using poly(ethylene glycol) (PEG) in precursor solution as an additive to fabricate perovskite solar cells with an 
power conversion efficiency (PCE) of $12.90 \%$ [42]. Zhao et al. showed stability improvement with addition of PEG into perovskite precursor solution due to the formation of a scaffold from the long-chain PEG polymers [43]. In 2016, Sun et al. used a two-step deposition process and incorporated polyvinylidene fluoride-trifluoroethylene polymer $\mathrm{P}(\mathrm{VDF}-\mathrm{TrFE})$ into PbI2 solution, achieving a PCE up to $12.94 \%$ [44]. Dong et al. utilized polymer additive polyethylenimine (PEI) to tune the morphology of perovskite films, boosting the PCE to $14.07 \%$ [45]. In 2017, Zuo et al. added polymer poly(4-vinylpyridine) (PVP) into $\mathrm{CH} 3 \mathrm{NH} 3 \mathrm{PbI} 3$ (MAPbI3) film. The resulting devices showed PCE up to $19.1 \%$ and retained $85 \%$ of the initial efficiency after 90 days [46]. In 2018, Jiang et al. tried various polymer semiconductors to dope the MAPbI3 layer, obtaining PCE well above 18\% [47]. In 2019, Han et al. adopted poly(propylene carbonate) (PPC) as a polymeric additive to investigate its effect on the formation and growth kinetics of perovskite layer [48].

Here, we investigated the effects of polyamidoamine (PAMAM) dendrimers as a kind of powerful additive on the regulation of perovskite thin film nucleation and growth. We have incorporated PAMAM into a blend solution of lead iodide $\left(\mathrm{PbI}_{2}\right)$ and methylammonium iodide (MAI) to tune the morphology and crystallinity of methylammonium lead iodide $\left(\mathrm{MAPbI}_{3}\right)$ perovskite films. The amine rich PAMAM additive chelates strongly with $\mathrm{Pb}^{2+}$ ions during film formation. The nucleation and growth of perovskite thin film thus can be well mediated and regulated by the amount of PAMAM additive. There is a recent publication that PAMAM was also utilized to manipulate perovskite morphology and attain compact and uniform thin films [49]. This polymer additive assisted one-step method represents a facile route for the controllable fabrication of smooth perovskite thin films for planar PVSCs. Furthermore, a rapid annealing approach has been developed by using a regular incandescent lamp to rapidly anneal perovskite films. In this study, the devices employ a simple planar $\mathrm{p}-\mathrm{i}-\mathrm{n}$ structure ITO/PEDOT:PSS $/ \mathrm{MAPbI}_{3} / \mathrm{PCBM} / \mathrm{Al}$. The perovskite solar cells from $250 \mathrm{~W}$ incandescent lamp annealing for $30 \mathrm{~s}$ on wood holder show PCE of $10.3 \%$ as compared with efficiency around $9 \%$ from hotplate annealing for $60 \mathrm{~min}$. The facile lamp annealing paves a way for speedy manufacturing of perovskite solar cells thereby reducing fabrication cost while maintaining device performance.

\section{Experiments}

\subsection{Materials}

$\mathrm{PbI}_{2}$ (beads, 99.9999\%) was purchased from Sigma-Aldrich, St. Louis, MO, USA. Methylammonium iodide (MAI) was purchase from Dyesol. Polyamidoamine (PAMAM, G3, 10\% wt in methanol) was purchased from Sigma-Aldrich. Dimethylformamide (DMF), chlorobenzene (CB), dichlorobenzene (DCB), diethyl ether (DE), and toluene were purchased from VWR. PEDOT:PSS and PCBM were purchased from Alfa Aesar and Nano-C, respectively. All the chemicals were used as-received without any further purification.

\subsection{Solution Preparation and Thin Film Deposition}

$\mathrm{PbI}_{2}$ and MAI were dissolved in DMF at a concentration of $1 \mathrm{~mol} / \mathrm{L}$ and stirred at $70{ }^{\circ} \mathrm{C}$ overnight to make sure the complete dissolution of both MAI and $\mathrm{PbI}_{2}$. The PAMAM (in methanol) solution was added into $\mathrm{PbI}_{2} / \mathrm{MAI}$ solution with stirring before spin-coating on PEDOT:PSS substrate. Solutions with various PAMAM loading in weight have been prepared for optimization of perovskite thin film. The resultant films were annealed at $100{ }^{\circ} \mathrm{C}$ for different time intervals.

\subsection{Film Characterization}

X-ray diffraction (XRD) measurements were conducted with a Bruker D8 X-ray diffractometer with a conventional cobalt target X-ray tube set to $40 \mathrm{KV}$ and $30 \mathrm{~mA}$. The absorption thin perovskite films was measured using a Beckman D 800 UV-Visible spectrometer. SEM images were taken by using a Joel 7000 Scanning Electron Microscope.

Device Fabrication: Substrates were cleaned in detergent followed by sonication in deionized water, acetone, and isopropanol for $40 \mathrm{~min}$, respectively. Substrates were then 
subjected to oxygen plasma for $30 \mathrm{~min}$. Substrates were heated on hot plate maintained at $80{ }^{\circ} \mathrm{C}$ for $5 \mathrm{~min}$ and PEDOT:PSS films were spin coated at $5000 \mathrm{rpm}$ for $45 \mathrm{~s}$ and annealed at $140{ }^{\circ} \mathrm{C}$ for $15 \mathrm{~min}$. A blend of $1 \mathrm{M}$ (precisely $461 \mathrm{mg} \mathrm{mL}^{-1}$ ) $\mathrm{PbI}_{2}$ (Sigma-Aldrich) and $1 \mathrm{M}$ (precisely $159 \mathrm{mg} \mathrm{mL}^{-1}$ ) MAI dissolved in anhydrous dimethylformamide (SigmaAldrich) was used as a precursor solution. After $1 \mathrm{wt} \%$ PAMAM dendrimer solution (optimal loading) was added to the precursor blend and stirred, the resulting solution was spin coated on PEDOT:PSS deposited substrate at $2000 \mathrm{rpm}$ for $10 \mathrm{~s}$ and $4000 \mathrm{rpm}$ for $45 \mathrm{~s}$. During the spin coating of precursor solution, after 8-10 s about $0.5 \mathrm{~mL}$ of toluene and diethyl ether solvents were dropped on the substrate.

Hot-plate annealing: The as-spin-coated substrates were then moved onto a hot plate maintained at $100{ }^{\circ} \mathrm{C}$ and annealed for $60 \mathrm{~min}$ inside the glove box.

Lamp annealing: A $125 \mathrm{~W}$ and a $250 \mathrm{~W}$ incandescent lamp were used as the heating source (Sylvania lighting company, Newhaven, UK). Substrates were transferred in petridish out of the glove-box and they were placed on three different bases (wood, metal, and glass). Distance between the top of the base or holder and the bottom of the lamp was maintained at about 3 inches and was undisturbed throughout the annealing process. After annealing, $20 \mathrm{mg} \mathrm{mL}^{-1}$ of PC71BM (Nano-C) solution was spin coated at $2000 \mathrm{rpm}$ for $30 \mathrm{~s}$ and annealed at $100{ }^{\circ} \mathrm{C}$ for $30 \mathrm{~min}$. The devices were completed by $100 \mathrm{~nm}$ thermal evaporation of $\mathrm{Al}$ at $2 \mathrm{~A}^{\circ} / \mathrm{s}$.

\subsection{Device Measurements}

The J-V curves of devices were measured with a semiconductor device analyzer (Agilent B1500A, Santa Clara, CA, USA) under solar simulator at air mass (AM) 1.5 condition. The solar simulator (Newport 91195A, Newport, UK) had an intensity of $100 \mathrm{~mW} \mathrm{~cm}^{-2}$ calibrated by a standard silicon cell (Oriel 91150V, New York, NY, USA).

\section{Results and Discussion}

PAMAM weight percentage and thermal annealing time. Based on X-ray diffraction (XRD) patterns of perovskite thin films with different ratios of PAMAM additives shown in Figure 1a, it has been found that the presence of PAMAM dendrimers regulates the nucleation and growth of perovskite thin films. As the amount of PAMAM increases from $0.5 \mathrm{wt} \%$ to $2.0 \mathrm{wt} \%$, the ratio of peak intensity at $16.5^{\circ}$ and $32.8^{\circ}$ decreases, suggesting the inhibition of nucleation and growth of perovskite along the (110) direction. The effect of hotplate annealing time has also been investigated on the nucleation of perovskite thin film with PAMAM polymers. The precursor solution contains equal moles of $\mathrm{PbI}_{2}$ and MAI, thus ideally there would be no peaks from both $\mathrm{MAI}$ and $\mathrm{PbI}_{2}$ if all the precursors convert into $\mathrm{MAPbI}_{3}$ perovskite. However, in Figure $1 \mathrm{~b}$, there exists MAI peaks at 2 theta of around $12^{\circ}$ from short period of time of thermal annealing (10 min and $\left.20 \mathrm{~min}\right)$, indicating a strong interaction between $\mathrm{PbI}_{2}$ and $\mathrm{PAMAM}$, which competes with $\mathrm{MAI}$ for reacting with $\mathrm{Pb}^{2+}$. After 30 min of thermal annealing, all the MAI peaks disappear and generate pure thin films of $\mathrm{MAPbI}_{3}$ perovskite. Above observations from XRD characterization clearly indicate that the highly branched PAMAM dendrimers can strongly interact with $\mathrm{Pb}^{2+}$. It is expected that the amine functional groups of PAMAM chelate with $\mathrm{Pb}^{2+}$ in the blend solution and hinder the combination of $\mathrm{Pb}$ ions and MAI to form $\mathrm{MAPbI}_{3}$ perovskite. Because of this interaction, the kinetics of $\mathrm{MAPbI}_{3}$ perovskite growth can be tuned by adjusting the amount of PAMAM in the blend solution to grow dense and ultra-smooth perovskite thin films. The optical properties of perovskite thin films with PAMAM have been investigated by using ultraviolet-visible (UV-Vis) spectroscopy. The PAMAM concentration-dependent $\mathrm{UV}$-Vis spectra are shown in Figure 1c, from which we find that the light absorption of perovskite thin film can be enhanced by increasing the amount of PAMAM, resulting in more compact and dense film. 

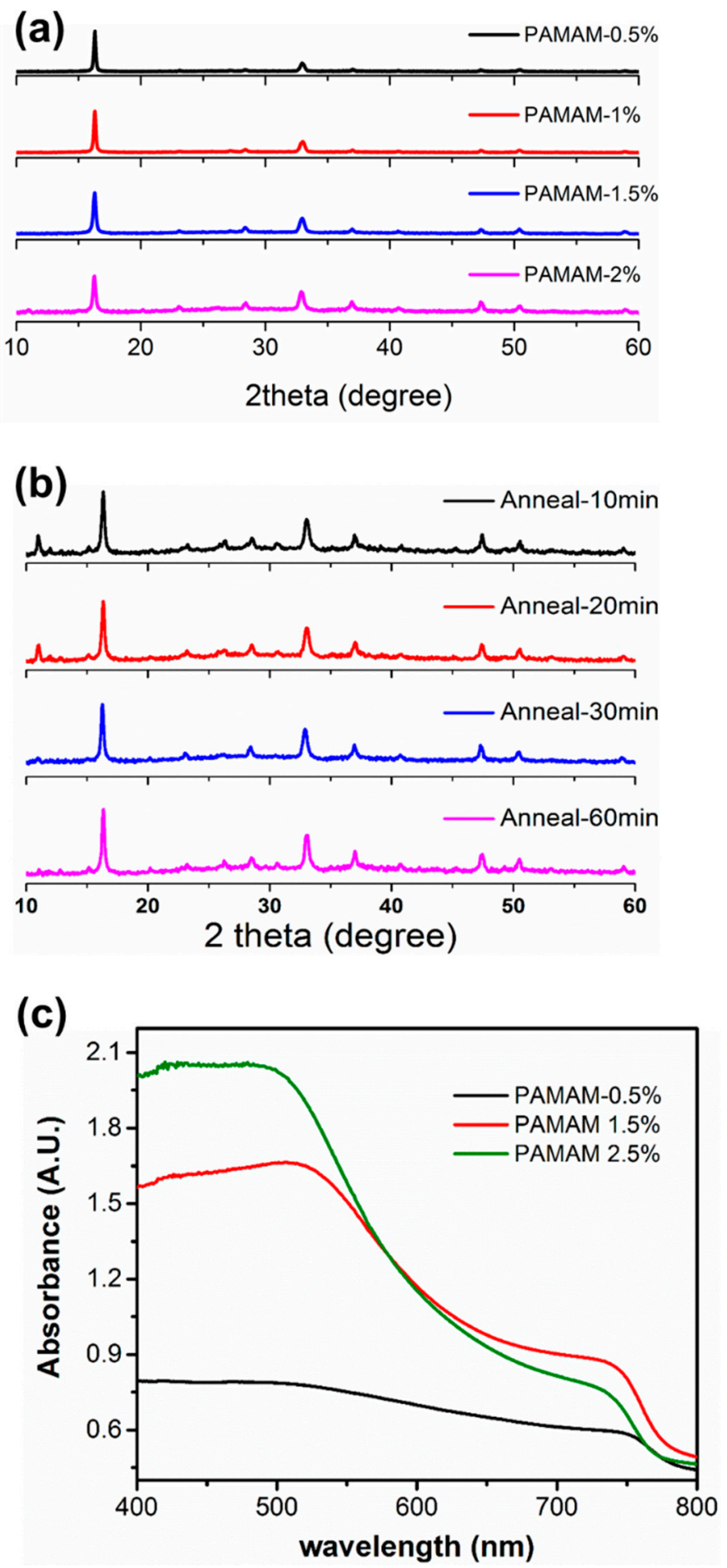

Figure 1. (a) XRD patterns of perovskite thin films with different weight percentages of PAMAM dendrimers (annealing at $100{ }^{\circ} \mathrm{C}$ for $60 \mathrm{~min}$ ); (b) XRD patterns of perovskite thin films with $1 \mathrm{wt} \%$ of PAMAM at $100{ }^{\circ} \mathrm{C}$ for different annealing times; (c) UV-Vis spectra of perovskite thin films with PAMAM loading of $0.5 \%, 1.5 \%$, and $2.5 \%$ in weight.

Effect of different anti-solvents. Different anti-solvents have been used to wash the perovskite film during the spin-coating deposition to improve the surface morphology and remove the residues of unreacted $\mathrm{MAI}$ and $\mathrm{PbI}_{2}$. SEM images in Figure 2a show thin-film morphologies after washing with four different anti-solvents, including chlorobenzene (CB), dichlorobenzene (DCB), diethyl ether (DE), and toluene, yielded perovskite films with similar grain size. Compared with other three anti-solvents, DCB produced non-uniform 
films with needle-like features on the film surface. XRD was carried out to investigate the composition of the films washed with $\mathrm{CB}, \mathrm{DCB}, \mathrm{DE}$, and toluene anti-solvents, as shown in Figure 2b. It was found that all the films showed identical perovskite peaks except for DCB-washed films, which presented an obvious $\mathrm{PbI}_{2}$ peak. The $\mathrm{XRD}$ results explain the origin of needle-like defects on the DCB-washed films displayed in the SEM image, which can be attributed to the incomplete conversion of precursors.

\section{(a)}

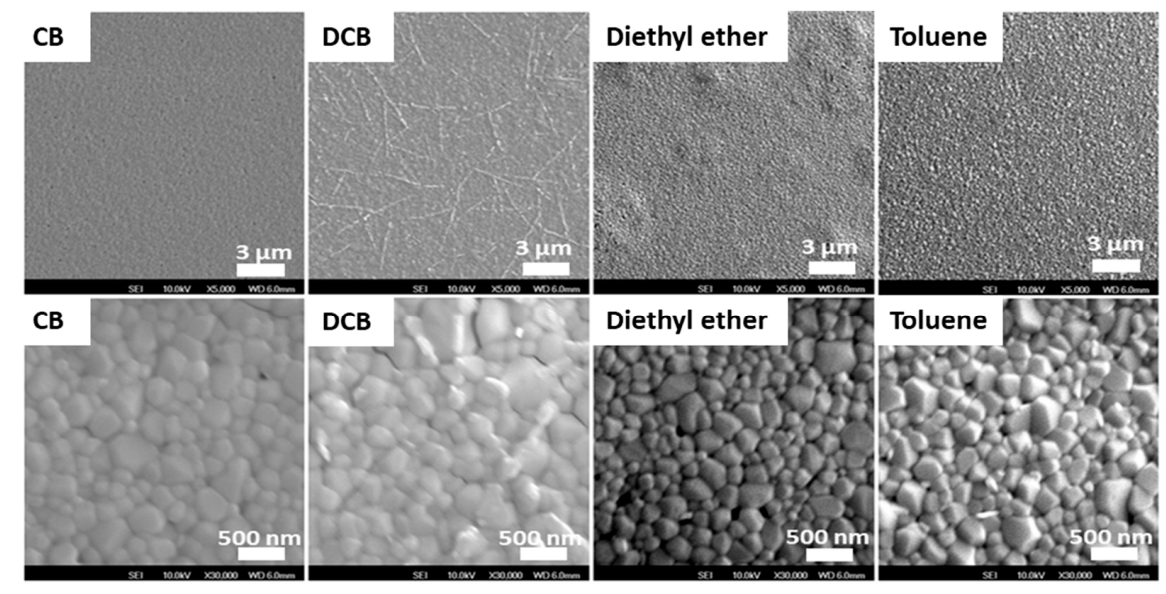

(b)

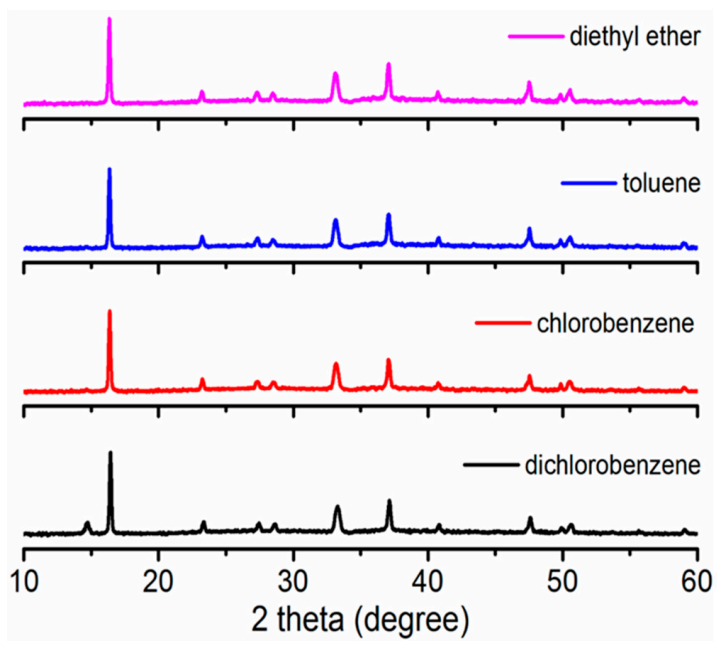

Figure 2. (a) SEM images of perovskite-PAMAM (1 wt \%) thin films washed by different anti-solvents, including chlorobenzene, dichlorobenzene, diethyl ether, and toluene; (b) Corresponding XRD patterns. All films were annealed on a hotplate at $100{ }^{\circ} \mathrm{C}$ for $60 \mathrm{~min}$ before SEM observations and XRD measurement.

Rapid lamp annealing of perovskite thin films. In addition to anti-solvent washing, annealing also plays a critical role to ensure optimal film crystallization thereby attaining high quality perovskite films. Typically, a hotplate is used for thermal annealing of perovskite films. For hotplate annealing of perovskite thin films with incorporation of PAMAM dendrimers, long period of time is needed to fully convert the $\mathrm{PbI}_{2}$ and $\mathrm{MAI}$ into $\mathrm{MAPbI}_{3}$ perovskite. Perovskite thin films annealed with hotplate for less than 30 min showed the presence of a peak at $\sim 12^{\circ}$ (Figure 1b), which is the characteristic peak of MAI [50]. Only hotplate annealing over $30 \mathrm{~min}$, pure perovskite thin films can be obtained free of both $\mathrm{PbI}_{2}$ and MAI residues. Such long annealing time makes the fabrication of perovskite solar cells incompatible with scale-up manufacturing through roll-to-roll (R2R) printing. In contrast, annealing of perovskite films using an incandescent lamp holds major advantages over the conventional hotplate annealing, including rapid heating and uniform temperature 
distribution. The majority of the electromagnetic radiation from the incandescent lamp used in this study falls in near-infrared range with some visible light. Infrared light (IR) is well-known for its heating effect. When IR light is absorbed by spin-coated precursor films, it stimulates vibrational modes within the molecules and heat up the material. Once the film becomes darker in color, the visible light from the lamp also provides energy to facilitate the crystallization of the target films. By increasing the lamp power, large number of photons can bring the thin films to intended temperatures in a much short annealing time. Moreover, with an incandescent lamp as the energy source, holders on which the Indium Tin Oxide (ITO) substrate resides on, can be used to manipulate the substrate temperature.

Lamp annealing was first conducted by using a $125 \mathrm{~W}$ incandescent light bulb with flat surface facing the substrate. During the lamp annealing process, the distance between the top of the supporting plate and the surface of the lamp was maintained at 3 inches. Sample substrates coated with perovskite precursor thin films were placed on a supporting plate, which can be metal, wood, or glass. Figure 3a shows the sample temperature versus annealing (radiation) time. When sample substrates were placed on the wood holder, it takes $5 \mathrm{~min}(300 \mathrm{~s})$ for samples to reach $100{ }^{\circ} \mathrm{C}$, which is the required temperature for annealing perovskite thin films on hotplates [51]. However, when sample substrates were placed on either iron metal or glass holders, in 5 min their temperature can only reach about $43^{\circ} \mathrm{C}$ and $60^{\circ} \mathrm{C}$, respectively, far away from the targeted $100^{\circ} \mathrm{C}$ annealing temperature. Then the $125 \mathrm{~W}$ lamp was replaced by a $250 \mathrm{~W}$ lamp for doubling the power of photonic annealing. The temperature of samples for different annealing time under radiation of $250 \mathrm{~W}$ lamp are shown in Figure 3b. Sample temperature increases quickly when these samples are placed on the wood holder. It only took $30 \mathrm{~s}$ for samples to reach the aimed annealing temperature of $100^{\circ} \mathrm{C}$ on the wood plate. On the other hand, the temperature of samples placed on either the iron metal or the glass holders increased much slower as the annealing time increased. It took $1 \mathrm{~min}$ and $3 \mathrm{~min}$ for samples to reach $100{ }^{\circ} \mathrm{C}$ on the iron metal and glass holders, respectively. As shown in Figure 3, the material of the sample holder does matter for the heating procedure in the lamp annealing. In this study, iron metal, glass, and wood holders with thermal conductivity of $\sim 80,1$, and $0.1 \mathrm{~W} /(\mathrm{mK})$, respectively, were used as substrate holder for studying the heating effect of the lamp annealing. The wood holder gives much higher annealing temperatures in a shorter time than iron and glass holders. This can be attributed to that wood has a much lower thermal conductivity than that of iron and glass, plus it is opaque and does not allow radiation to pass through (glass) or reflect from (iron). It is hard for the produced thermal energy to be accumulated on iron plate because of its high thermal conduction for heat dissipation. On the other hand, although glass has much lower thermal conductivity, its transparency spares part of the incoming radiation energy, resulting in less generation of heat and slower temperature increase.

Film quality and device performance of lamp annealed perovskite solar cells with incorporation of PAMAM dendrimers. SEM monographs in Figure 4a show uniform and smooth perovskite films with addition of PAMAM dendrimers at optimal $1 \mathrm{wt} \%$ loading under lamp annealing. Without addition of PAMAM dendrimers, the perovskite film made from pre-mixed $\mathrm{PbI}_{2}$ and MAI solutions is composed of fiber like structure and with a large amount of pin holes on it. Too little PAMAM addition may not function well to form high-quality film. On the other hand, too much loading could negatively affect charge transport and efficiency because of insulating nature of PAMAM dendrimers. All films were washed by toluene during spin coating. Compared to $1 \mathrm{~h}$ annealing on hotplate, the dense thin films with ultra-smooth surface morphology can be attained in less than 1 min by lamp annealing. Based on the XRD spectra shown in Figure $4 b$, only perovskite peaks are observed and no crystal peaks from $\mathrm{PbI}_{2}$ and MAI precursors appear, indicating complete conversion of precursors into perovskite in the rapid lamp annealing. From the current density versus voltage (J-V) characteristics in Figure 4c, PVSCs with lamp annealing of $30 \mathrm{~s}$ on wood plate show even better performance with a PCE of $10.3 \%$ than PCE of $9.0 \%$ from hotplate annealing for $1 \mathrm{~h}$. That is, rapid lamp annealing could improve 
efficiency while significantly reducing the annealing time. Table 1 lists device parameters extracted from J-V characteristics, including PCE, fill factor (FF), open-circuit voltage (Voc), and short-circuit current density (Jsc).
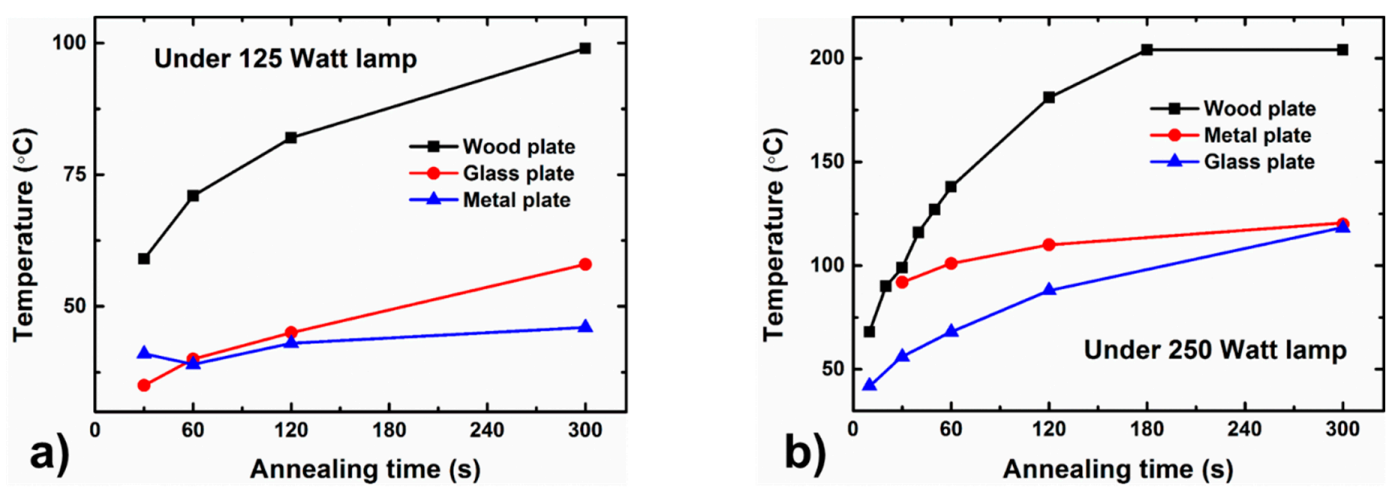

Figure 3. Sample temperature versus lamp annealing time under (a) $125 \mathrm{~W}$ lamp and (b) $250 \mathrm{~W}$ lamp when placed on wood, iron metal and glass sample supporting plates.

(a)

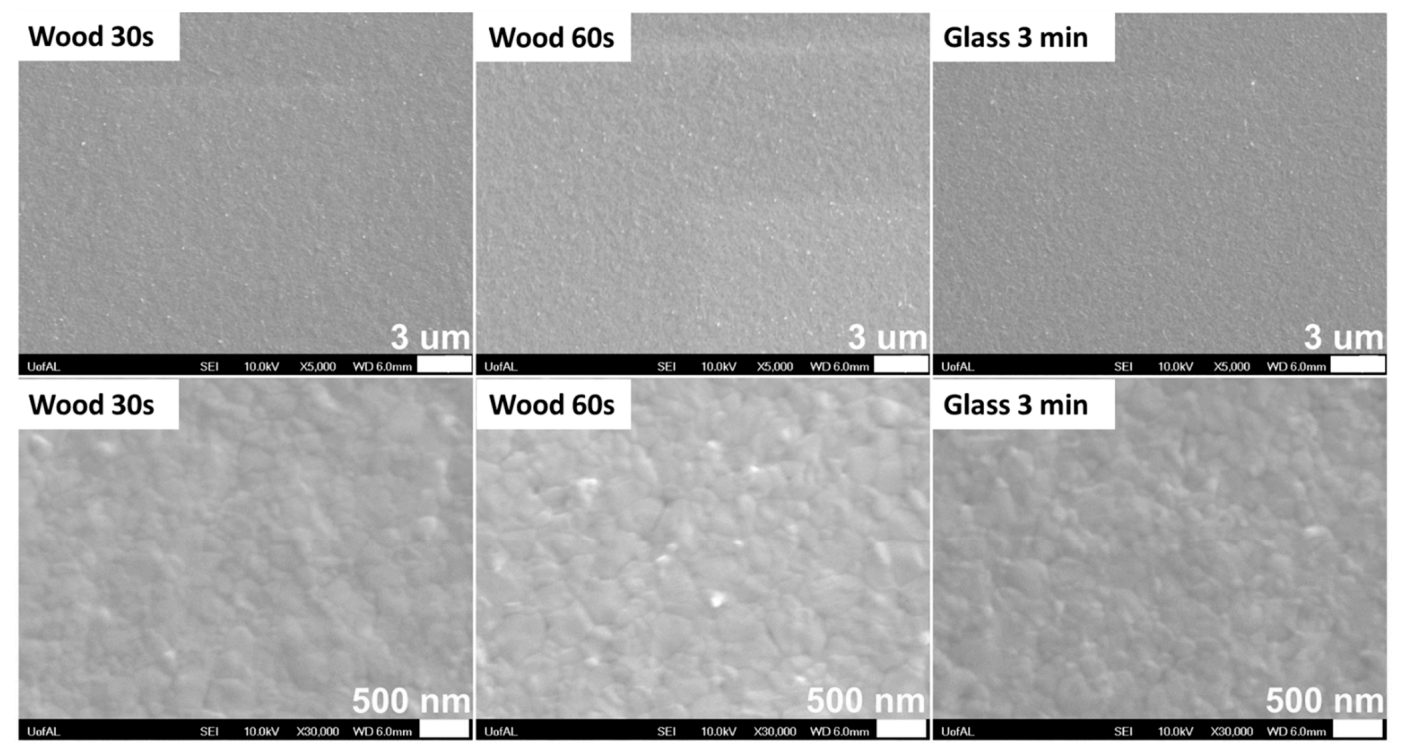

(b)

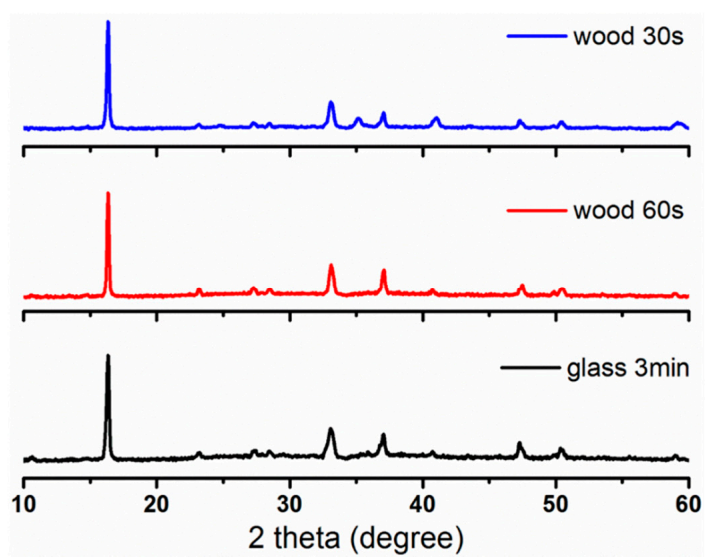

(c)

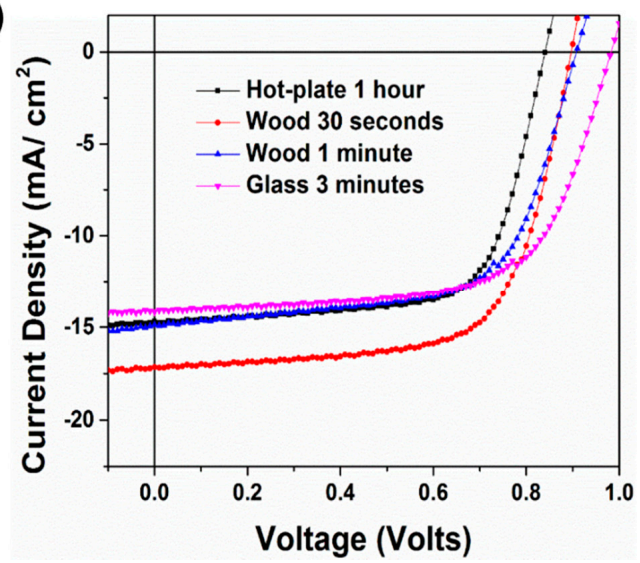

Figure 4. (a) SEM monographs show morphologies of perovskite films with addition of PAMAM (1 wt $\%$ ) under various lamp annealing conditions, including $30 \mathrm{~s}$ for samples on wood plate, $60 \mathrm{~s}$ also on wood plate, and 3 min on glass sample holder; (b) Corresponding XRD spectrum; (c) Comparison of J-V characteristics between fast lamp annealing with samples on wood and glass holders and traditional hotplate annealing. 
Table 1. Device parameters extracted from J-V characteristics of PVSCs with $1 \mathrm{wt} \%$ PAMAM loading.

\begin{tabular}{ccccc}
\hline & PCE (\%) & FF & Voc (V) & Jsc (mA/cm $\left.\mathbf{c}^{\mathbf{}}\right)$ \\
\hline $\begin{array}{c}\text { Hot-plate annealing } \\
\mathbf{( 1 ~ h )}\end{array}$ & 9.0 & 70.49 & 0.84 & 15.13 \\
\hline $\begin{array}{c}\text { IR lamp annealing } \\
\text { (wood, 30 s) }\end{array}$ & 10.3 & 68.44 & 0.88 & 17.14 \\
\hline $\begin{array}{c}\text { IR lamp annealing } \\
\text { (wood, 1 min) }\end{array}$ & 8.6 & 64.45 & 0.9 & 14.88 \\
\hline $\begin{array}{c}\text { IR lamp annealing } \\
\text { (wood, 3 min) }\end{array}$ & 9.1 & 65.91 & 0.97 & 14.17 \\
\hline
\end{tabular}

\section{Conclusions}

In summary, a new method for deposition of perovskite films has been demonstrated by introducing polyamidoamine (PAMAM) polymer as an additive to control the growth and nucleation of perovskite films. A lamp annealing approach has been developed to rapidly anneal perovskite films using an incandescent lamp, which can rapidly heat sample up with great uniformity as compared with the traditional hotplate annealing. The PAMAM-containing perovskite solar cells annealed by a $250 \mathrm{~W}$ incandescent lamp in less than 3 min showed similar or even better device performance than reference devices obtained by annealing on a hotplate for $60 \mathrm{~min}$. Particularly, perovskite solar cells with fast lamp annealing for $30 \mathrm{~s}$ on a wood holder showed an efficiency of $10.3 \%$ as compared with an efficiency of $9.0 \%$ for solar cells obtained by hotplate annealing for $60 \mathrm{~min}$. These results not only exhibit an enhanced effectiveness of lamp annealing over hotplate annealing, but also prove the feasibility of using the facile polymer additive approach for the deposition of perovskite thin films.

Author Contributions: Conceptualization, D.L. and Z.Z.; investigation and formal analysis, S.S., Z.Z., Z.O., R.H. and D.L.; writing_original draft preparation, Z.Z., S.S., Z.O. and R.H.; writing-review and editing, D.L.; supervision, D.L.; funding acquisition, D.L. All authors have read and agreed to the published version of the manuscript.

Funding: This work was partially supported by National Science Foundation \#1919259.

Institutional Review Board Statement: Not applicable.

Informed Consent Statement: Not applicable.

Data Availability Statement: Not applicable.

Acknowledgments: D.L. acknowledges the postdoctoral research fellowship support for Z.Z. from the University of Alabama. D.L. thanks the graduate student scholarship for Z.O. and high-school summer internship for R.H. from the Center for Materials for Information Technology (MINT) at the University of Alabama.

Conflicts of Interest: The authors declare no competing financial interest.

\section{References}

1. Saparov, B.; Mitzi, D.B. Organic-Inorganic Perovskites: Structural Versatility for Functional Materials Design. Chem. Rev. 2016, 116, 4558-4596. [CrossRef]

2. Wang, W.; Tadé, M.O.; Shao, Z. Research progress of perovskite materials in photocatalysis- and photovoltaics-related energy conversion and environmental treatment. Chem. Soc. Rev. 2015, 44, 5371-5408. [CrossRef] [PubMed]

3. Zhao, Y.; Zhu, K. Organic-inorganic hybrid lead halide perovskites for optoelectronic and electronic applications. Chem. Soc. Rev. 2016, 45, 655-689. [CrossRef]

4. Burschka, J;; Pellet, N.; Moon, S.-J.; Humphry-Baker, R.; Gao, P.; Nazeeruddin, M.K.; Grätzel, M. Sequential deposition as a route to high-performance perovskite-sensitized solar cells. Nat. Cell Biol. 2013, 499, 316-319. [CrossRef] [PubMed]

5. Carnie, M.J.; Charbonneau, C.; Davies, M.L.; Troughton, J.; Watson, T.M.; Wojciechowski, K.; Snaith, H.; Worsley, D.A. A one-step low temperature processing route for organolead halide perovskite solar cells. Chem. Commun. 2013, 49, 7893-7895. [CrossRef] [PubMed] 
6. Chen, Q.; Zhou, H.; Hong, Z.; Luo, S.; Duan, H.-S.; Wang, H.-H.; Liu, Y.; Li, G.; Yang, Y. Planar Heterojunction Perovskite Solar Cells via Vapor-Assisted Solution Process. J. Am. Chem. Soc. 2014, 136, 622-625. [CrossRef] [PubMed]

7. Xiao, Z.; Bi, C.; Shao, Y.; Dong, Q.; Wang, Q.; Yuan, Y.; Wang, C.; Gao, Y.; Huang, J. Efficient, high yield perovskite photovoltaic devices grown by interdiffusion of solution-processed precursor stacking layers. Energy Environ. Sci. 2014, 7, $2619-2623$. [CrossRef]

8. Boopathi, K.M.; Mohan, R.; Huang, T.-Y.; Budiawan, W.; Lin, M.-Y.; Lee, C.-H.; Ho, K.-C.; Chu, C.-W. Synergistic improvements in stability and performance of lead iodide perovskite solar cells incorporating salt additives. J. Mater. Chem. A 2016, 4, 1591-1597. [CrossRef]

9. Bi, C.; Wang, Q.; Shao, Y.; Yuan, Y.; Xiao, Z.; Huang, J. Non-wetting surface-driven high-aspect-ratio crystalline grain growth for efficient hybrid perovskite solar cells. Nat. Commun. 2015, 6, 7747. [CrossRef]

10. Li, B.; Tian, J.; Guo, L.; Fei, C.; Shen, T.; Qu, X.; Cao, G. Dynamic Growth of Pinhole-Free Conformal CH3NH3PbI3 Film for Perovskite Solar Cells. ACS Appl. Mater. Interfaces 2016, 8, 4684-4690. [CrossRef] [PubMed]

11. Liang, Q.; Liu, J.; Cheng, Z.; Li, Y.; Chen, L.; Zhang, R.; Zhang, J.; Han, Y. Enhancing the crystallization and optimizing the orientation of perovskite films via controlling nucleation dynamics. J. Mater. Chem. A 2015, 4, 223-232. [CrossRef]

12. Yang, Y.; Sun, C.; Yip, H.-L.; Sun, R.; Wang, X. Chitosan-Assisted Crystallization and Film Forming of Perovskite Crystals through Biomineralization. Chem. Asian J. 2016, 11, 893-899. [CrossRef] [PubMed]

13. Zhou, Y.; Game, O.S.; Pang, S.; Padture, N.P. Microstructures of Organometal Trihalide Perovskites for Solar Cells: Their Evolution from Solutions and Characterization. J. Phys. Chem. Lett. 2015, 6, 4827-4839. [CrossRef]

14. Eperon, G.E.; Burlakov, V.M.; Docampo, P.; Goriely, A.; Snaith, H.J. Morphological Control for High Performance, SolutionProcessed Planar Heterojunction Perovskite Solar Cells. Adv. Funct. Mater. 2014, 24, 151-157. [CrossRef]

15. Nie, W.; Tsai, H.; Asadpour, R.; Blancon, J.-C.; Neukirch, A.J.; Gupta, G.; Crochet, J.J.; Chhowalla, M.; Tretiak, S.; Alam, M.A.; et al. High-efficiency solution-processed perovskite solar cells with millimeter-scale grains. Science 2015, 347, 522-525. [CrossRef] [PubMed]

16. Williams, S.T.; Zuo, F.; Chueh, C.-C.; Liao, C.-Y.; Liang, P.-W.; Jen, A.K.-Y. Role of Chloride in the Morphological Evolution of Organo-Lead Halide Perovskite Thin Films. ACS Nano 2014, 8, 10640-10654. [CrossRef]

17. Cai, B.; Zhang, W.-H.; Qiu, J. Solvent engineering of spin-coating solutions for planar-structured high-efficiency perovskite solar cells. Chin. J. Catal. 2015, 36, 1183-1190. [CrossRef]

18. Rong, Y.; Tang, Z.; Zhao, Y.; Zhong, X.; Venkatesan, S.; Graham, H.; Patton, M.; Jing, Y.; Guloy, A.M.; Yao, Y. Solvent engineering towards controlled grain growth in perovskite planar heterojunction solar cells. Nanoscale 2015, 7, 10595-10599. [CrossRef]

19. Jeon, N.J.; Noh, J.H.; Kim, Y.C.; Yang, W.S.; Ryu, S.; Seok, S.I. Solvent engineering for high-performance inorganic-organic hybrid perovskite solar cells. Nat. Mater. 2014, 13, 897-903. [CrossRef]

20. Zhou, Y.; Yang, M.; Wu, W.; Vasiliev, A.L.; Zhu, K.; Padture, N.P. Room-temperature crystallization of hybrid-perovskite thin films via solvent-solvent extraction for high-performance solar cells. J. Mater. Chem. A 2015, 3, 8178-8184. [CrossRef]

21. Peng, W.; Anand, B.; Liu, L.; Sampat, S.; Bearden, B.E.; Malko, A.V.; Chabal, Y.J. Influence of growth temperature on bulk and surface defects in hybrid lead halide perovskite films. Nanoscale 2016, 8, 1627-1634. [CrossRef] [PubMed]

22. Song, Z.; Watthage, S.C.; Phillips, A.B.; Tompkins, B.L.; Ellingson, R.J.; Heben, M.J. Impact of Processing Temperature and Composition on the Formation of Methylammonium Lead Iodide Perovskites. Chem. Mater. 2015, 27, 4612-4619. [CrossRef]

23. Gao, H.; Bao, C.; Li, F.; Yu, T.; Yang, J.; Zhu, W.; Zhou, X.; Fu, G.; Zou, Z. Nucleation and Crystal Growth of Organic-Inorganic Lead Halide Perovskites under Different Relative Humidity. ACS Appl. Mater. Interfaces 2015, 7, 9110-9117. [CrossRef] [PubMed]

24. Eperon, G.E.; Habisreutinger, S.N.; Leijtens, T.; Bruijnaers, B.J.; van Franeker, J.J.; dequilettes, D.W.; Pathak, S.; Sutton, R.J.; Grancini, G.; Ginger, D.S.; et al. The Importance of Moisture in Hybrid Lead Halide Perovskite Thin Film Fabrication. ACS Nano 2015, 9, 9380-9393. [CrossRef] [PubMed]

25. Gong, X.; Li, M.; Shi, X.-B.; Ma, H.; Wang, Z.-K.; Liao, L.-S. Controllable Perovskite Crystallization by Water Additive for High-Performance Solar Cells. Adv. Funct. Mater. 2015, 25, 6671-6678. [CrossRef]

26. You, J.; Yang, Y.; Hong, Z.; Song, T.-B.; Meng, L.; Liu, Y.; Jiang, C.; Zhou, H.; Chang, W.-H.; Li, G.; et al. Moisture assisted perovskite film growth for high performance solar cells. Appl. Phys. Lett. 2014, 105, 183902. [CrossRef]

27. Zhang, M.; Yu, H.; Lyu, M.; Wang, Q.; Yun, J.-H.; Wang, L. Composition-dependent photoluminescence intensity and prolonged recombination lifetime of perovskite $\mathrm{CH} 3 \mathrm{NH} 3 \mathrm{PbBr3}-\mathrm{xClx}$ films. Chem. Commun. 2014, 50, 11727-11730. [CrossRef]

28. Ogomi, Y.; Morita, A.; Tsukamoto, S.; Saitho, T.; Fujikawa, N.; Shen, Q.; Toyoda, T.; Yoshino, K.; Pandey, S.S.; Ma, T.; et al. CH3NH3SnxPb(1-x)I3 Perovskite Solar Cells Covering up to $1060 \mathrm{~nm}$. J. Phys. Chem. Lett. 2014, 5, 1004-1011. [CrossRef]

29. Sadhanala, A.; Deschler, F.; Thomas, T.H.; Dutton, S.E.; Goedel, K.C.; Hanusch, F.C.; Lai, M.L.; Steiner, U.; Bein, T.; Docampo, P.; et al. Preparation of Single-Phase Films of CH3NH3Pb (I1-x, Br-x) (3) with Sharp Optical Band Edges. J. Phys. Chem. Lett. 2014, 5, 2501-2505. [CrossRef]

30. Jeon, N.J.; Noh, J.H.; Yang, W.S.; Kim, Y.C.; Ryu, S.; Seo, J.; Seok, S.I. Compositional engineering of perovskite materials for high-performance solar cells. Nat. Cell Biol. 2015, 517, 476-480. [CrossRef] [PubMed]

31. Li, T.; Pan, Y.; Wang, Z.; Xia, Y.; Chen, Y.; Huang, W. Additive engineering for highly efficient organic-inorganic halide perovskite solar cells: Recent advances and perspectives. J. Mater. Chem. A 2017, 5, 12602-12652. [CrossRef]

32. Wu, C.-G.; Chiang, C.-H.; Tseng, Z.-L.; Nazeeruddin, M.K.; Hagfeldt, A.; Grätzel, M. High efficiency stable inverted perovskite solar cells without current hysteresis. Energy Environ. Sci 2015, 8, 2725-2733. [CrossRef] 
33. Li, L.; Chen, Y.; Liu, Z.; Chen, Q.; Wang, X.; Zhou, H. The Additive Coordination Effect on Hybrids Perovskite Crystallization and High-Performance Solar Cell. Adv. Mater. 2016, 28, 9862-9868. [CrossRef]

34. Heo, J.H.; Han, H.J.; Kim, D.; Ahn, T.K.; Im, S.H. Hysteresis-less inverted CH3NH3PbI3 planar perovskite hybrid solar cells with 18.1\% power conversion efficiency. Energy Environ. Sci. 2015, 8, 1602-1608. [CrossRef]

35. Heo, J.H.; Song, D.H.; Han, H.J.; Kim, S.Y.; Kim, J.H.; Kim, D.; Shin, H.W.; Ahn, T.K.; Wolf, C.; Lee, T.-W.; et al. Planar CH3NH3PbI3Perovskite Solar Cells with Constant 17.2\% Average Power Conversion Efficiency Irrespective of the Scan Rate. Adv. Mater. 2015, 27, 3424-3430. [CrossRef]

36. Chueh, C.-C.; Liao, C.-Y.; Zuo, F.; Williams, S.T.; Liang, P.-W.; Jen, A.K.-Y. The roles of alkyl halide additives in enhancing perovskite solar cell performance. J. Mater. Chem. A 2014, 3, 9058-9062. [CrossRef]

37. Abdi-Jalebi, M.; Dar, M.I.; Sadhanala, A.; Senanayak, S.P.; Franckevičius, M.; Arora, N.; Hu, Y.; Nazeeruddin, M.K.; Zakeeruddin, S.M.; Grätzel, M.; et al. Impact of Monovalent Cation Halide Additives on the Structural and Optoelectronic Properties of CH3NH3PbI3Perovskite. Adv. Energy Mater. 2016, 6, 1502472. [CrossRef]

38. Docampo, P.; Hanusch, F.C.; Stranks, S.D.; Döblinger, M.; Feckl, J.M.; Ehrensperger, M.; Minar, N.K.; Johnston, M.B.; Snaith, H.J.; Bein, T. Solution Deposition-Conversion for Planar Heterojunction Mixed Halide Perovskite Solar Cells. Adv. Energy Mater. 2014, 4, 1400355. [CrossRef]

39. Zhao, L.; Luo, D.; Wu, J.; Huang, Q.; Zhang, W.; Chen, K.; Liu, T.; Liu, Y.; Zhang, Y.; Liu, F.; et al. High-Performance Inverted Planar Heterojunction Perovskite Solar Cells Based on Lead Acetate Precursor with Efficiency Exceeding 18\%. Adv. Funct. Mater. 2016, 26, 3508-3514. [CrossRef]

40. Xue, Q.; Hu, Z.; Sun, C.; Chen, Z.; Huang, F.; Yip, H.-L.; Cao, Y. Metallohalide perovskite-polymer composite film for hybrid planar heterojunction solar cells. RSC Adv. 2015, 5, 775-783. [CrossRef]

41. Guo, Y.; Shoyama, K.; Sato, W.; Nakamura, E. Polymer stabilization of lead (II) perovskite cubic nanocrystals for semitransparent solar cells. Adv. Energy Mater. 2016, 6, 1502317. [CrossRef]

42. Chang, C.-Y.; Chun-Yu, C.; Huang, Y.-C.; Huang, C.-W.; Chang, S.-Y.; Chen, C.-A.; Chao, C.-Y.; Su, W.-F. Tuning Perovskite Morphology by Polymer Additive for High Efficiency Solar Cell. ACS Appl. Mater. Interfaces 2015, 7, 4955-4961. [CrossRef] [PubMed]

43. Hao, Y.; Wei, J.; Li, H.; Yan, Y.; Zhou, W.; Yu, D.; Zhao, Q. A polymer scaffold for self-healing perovskite solar cells. Nat. Commun. 2016, 7, 10228. [CrossRef]

44. Sun, C.; Guo, Y.; Fang, B.; Yang, J.; Qin, B.; Duan, H.; Chen, Y.; Li, H.; Liu, H. Enhanced photovoltaic performance of perovskite solar cells using polymer P (VDF-TrFE) as a processed additive. J. Phys. Chem. C 2016, 120, 12980-12988. [CrossRef]

45. Dong, Q.; Wang, Z.; Zhang, K.; Yu, H.; Huang, P.; Liu, X.; Zhou, Y.; Chen, N.; Song, B. Easily accessible polymer additives for tuning the crystal-growth of perovskite thin-films for highly efficient solar cells. Nanoscale 2016, 8, 5552-5558. [CrossRef]

46. Zuo, L.; Guo, H.; Dequilettes, D.W.; Jariwala, S.; De Marco, N.; Dong, S.; DeBlock, R.; Ginger, D.S.; Dunn, B.; Wang, M.; et al. Polymer-modified halide perovskite films for efficient and stable planar heterojunction solar cells. Sci. Adv. 2017, 3, e1700106. [CrossRef] [PubMed]

47. Jiang, J.; Wang, Q.; Jin, Z.; Zhang, X.; Lei, J.; Bin, H.; Zhang, Z.G.; Li, Y.; Liu, S. Polymer doping for high-efficiency perovskite solar cells with improved moisture stability. Adv. Energy Mater. 2018, 8, 1701757. [CrossRef]

48. Han, T.-H.; Lee, J.-W.; Choi, C.; Tan, S.; Lee, C.; Zhao, Y.; Dai, Z.; De Marco, N.; Lee, S.-J.; Bae, S.-H.; et al. Perovskite-polymer composite cross-linker approach for highly-stable and efficient perovskite solar cells. Nat. Commun. 2019, 10, 520. [CrossRef] [PubMed]

49. Du, Y.; Wang, X.; Lian, D.; Liu, Y.; Zhang, L.; Xu, S.; Cao, S. Dendritic PAMAM polymers for strong perovskite intergranular interaction enhancing power conversion efficiency and stability of perovskite solar cells. Electrochim. Acta 2020, $349,136387$. [CrossRef]

50. Zhou, Z.; Shaik, S.; Ouyang, Z.; Yan, F.; Li, D. Rapid crystallization and controllable growth of perovskite thin films via a seeded approach. J. Vac. Sci. Technol. A 2019, 37, 021201. [CrossRef]

51. Ahn, N.; Son, D.-Y.; Jang, I.-H.; Kang, S.M.; Choi, M.; Park, N. Highly reproducible perovskite solar cells with average efficiency of $18.3 \%$ and best efficiency of $19.7 \%$ fabricated via Lewis base adduct of lead (II) iodide. J. Am. Chem. Soc. 2015, 137, 8696-8699. [CrossRef] [PubMed] 